\title{
ポリマー多層膜光素子
}

\author{
小見門利行，井上 梓，増田康一，安藤 隆史，梅垣 真祐 \\ 慶應義塾大学 理工学部（テ223-8522 神奈川県横浜市港北区日吉3-14-1)
}

\section{Optical Devices Using Polymeric Multi-Layers}

\author{
Toshiyuki KOMIKADO, Azusa INOUE, Koichi MASUDA, Takashi ANDO, and Shinsuke UMEGAKI \\ Faculty of Science and Technology, Keio University, 3-14-1 Hiyoshi, Kohoku-ku, Yokohama, Kanagawa 223-8522
}

(Received April 5, 2004)

\begin{abstract}
High-reflection multi-layered mirrors have ever been fabricated using inorganic dielectric materials. Their fabrication methods are almost all based on vacuum evaporation or sputtering. On the other hand, polymeric thin-films such as photo-resists can be easily obtained by spin coating. In this study, we report the results of fabrication of the multi-layered mirrors by spin coating of two different polymers. Optical thickness of layers for $\lambda 4$ was controlled by adjusting concentration of solutions and by changing rotation speed of spin coating. Simple repetitive-processes of spin coating and drying solvents yielded reflectivity higher than $99 \%$ at a wavelength of $633 \mathrm{~nm}$ after stacking 49 layers. We also report possible applications for novel photonic-devices using polymeric high-reflection multi-layered mirrors or all-polymeric functional devices.
\end{abstract}

Key Words: Polymeric multi-layered mirror, Spin coating, All-polymeric device

1.はじめに

光学多層膜は高反射ミラー, 干渉フィルター, 反射防 止膜などに用いられる。これらは $1 / 4$ 波長光学膜厚を交互 積層したり，1/2波長の奇数倍の中間層を設けたりして構 成されるが, 従来, 金属や $\mathrm{TiO}_{2}, \mathrm{SiO}_{2}$ などの無機誘電体を 用いて真空蒸着法, スパッタリング法, イオンアシスト 法などにより作製されてきた。真空中での作製では水晶 振動子のモニターによる精密な膜厚制御が可能である反 面, 化学量論的組成を有する薄膜を得るため $\mathrm{O}_{2}$ 分圧, 基 板温度などのパラメーターを調整・制御する必要があ る. 結果として高コストの真空設備, 技術の蓄積が必要 となる。

近年，ガラスに代わる光学材料としてポリマー，プラ スティックスが軽量性，加工性の良さから盛んに利用さ れるようになってきた。透明なポリマー材料の開発に伴 い，ポリマー基板上への無機誘電体多層膜コーティング が研究1,2)されてはいるが，ポリマー自身の多層膜化に関 する研究は極めて少ない. ポリマー材料の薄膜作製技術 は多様である，射出成形，キャスティング，ディップ コート，スプレー，スピンコートなどのウェットプロセ ス，無機材料と同様のスパッタリング法などのドライプ ロセス等, 多岐にわたる. 中でもスピンコートによる薄 膜作製は，半導体製造工程におけるフォトレジストの塗 布, DVD光ディスクの色素記録層の成膜など簡便かつ安
価な方法として広く利用され，スピンコート時の溶液膜 の流動解析 ${ }^{3,4)}$, 均一薄膜形成過程の条件解析 ${ }^{5)}$ 女数多く報 告されている。本稿では, 真空環境を用いず，ポリマー 溶液のスピンコートと溶媒の乾燥を繰り返す, 安価で単 純なプロセスを用い, 膜厚を制御して高反射多層膜を作 製した結果およびその耐光性を評価した結果について述 へ，無機材料には無いポリマー材料の可撓性や染色性を 活かした素子応用を探る。

\section{2. 高反射多層膜の研究動向}

高反射多層膜の基本構造は, Fig. 1に示すように入/4光学 膜厚毎に高屈折率層，低屈折率層を交互積層した形と なっており，一種の1次元フォトニック結晶とみなすこと ができる。

膜面への垂直入射光に対する反射率 $R$ は式 (1)で与えら れる。

$$
R=\left[\frac{1-\left(n_{\mathrm{H}} / n_{\mathrm{L}}\right)^{2 q}\left(n_{\mathrm{H}}{ }^{2} / n_{\mathrm{S}}\right)}{1+\left(n_{\mathrm{H}} / n_{\mathrm{L}}\right)^{2 q}\left(n_{\mathrm{H}}{ }^{2} / n_{\mathrm{S}}\right)}\right]^{2}
$$

ここで, $n_{\mathrm{H}}, n_{\mathrm{L}}$ は高屈折率層 $(\mathrm{H}$ 層), 低屈折率層 (L層)の 屈折率， $n_{\mathrm{S}}$ は基板の屈折率， $q$ は (HL) 層の周期数である. 式(1) から, 屈折率比 $n_{\mathrm{H}} / n_{\mathrm{L}}$ が大きいほど低積層数で高反射 が実現でき，その帯域幅が広くなることがわかる。一般 


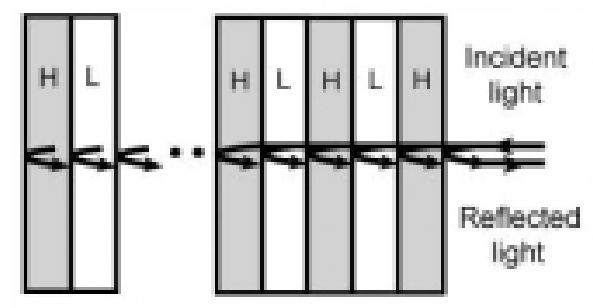

Fig. 1 Multi-layered structure for high reflection.

に可視から近赤外域レーザー出力鏡用材料としては，こ の領域で透明な無機誘電体 $\mathrm{TiO}_{2}, \mathrm{SiO}_{2}$ の組合せや $\mathrm{Ta}_{2} \mathrm{O}_{5}$, $\mathrm{SiO}_{2}$ などが用いられている。

高反射多層膜作製法やその材料に関する研究は概ね3つ の動向に分けられる。(1)屈折率比の大きな材料の開発, (2)作製手法の改良あるいは新規作製法の開発，(3)多層膜 素子の機能化である。

(1) L 層用無機材料 $\mathrm{SiO}_{2}$ より屈折率が低く, 紫外から近 赤外域にかけて透明な有機ポリマーとしてテフロン $\mathrm{AF}$ フルオロカーボンポリマー $\left(\mathrm{CF}_{\mathrm{x}}\right)$ がある，前者では無機材 料ZnSをH層として用い熱蒸着6)により (HL)の周期数4/合 計9層で98\% (1064 nm)が達成され, 後者では $\mathrm{TiO}_{2}$ を層と して用いイオンビームスパッタ法7)により周期数3/合計7 層で98\%(850 nm), 周期数6/合計 13 層で $99 \%(350 \mathrm{~nm})$ が 得られている。逆にポリマー側を高屈折率とした例とし て， $\mathrm{CF}_{\mathrm{x}}$ に金微粒子を共スパッターして1.35近辺の屈折率 を1.7まで高くした例8)，ポリフェニレンビニレンに $\mathrm{TiO}_{2}$ ナ ノ微粒子を分散させてH層もL層も作製した例9,10)がある.

(2) 屈折率の異なる2種のポリマーを用いたスピンコー 卜法による作製11,12)，ブロック重合ポリマーの自己組織化 を利用して屈折率周期構造を生成する方法 ${ }^{13,14)}$, ゾルゲル 溶液による作製15)，2種のポリマー前駆体の気相からのプ ラズマ重合による高屈折率比をもつポリマー多層膜の作 製16)などが挙げられる.

(3) 面発光レーザーに用いられる半導体DBR ${ }^{17)}$ を導電性 ポリマーによって実現した例19), ポリマー多層膜厚の圧 力, 温度による可変化 ${ }^{11)}$ な゙がある.

\section{3. ポリマーのスピンコート法による 高反射多層膜の作製}

2種のポリマーのスピンコーティングにより所望の光学 多層膜ができれば，高コストの真空環境が不要となり， 汎用的なスピナーを用いて簡便な作製が可能となる。こ

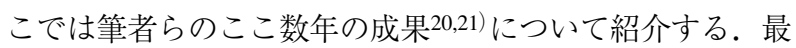
近になってわかったことであるが，スピンコート法によ る高反射多層膜の作製は筆者らが最初ではない. Kimura ら11にによって25年前に試みられていた。2種のポリマーと して，H層にはポリスチレン (PS: $\mathrm{n}=1.58,600 \mathrm{~nm})$, L層 にはポリビニルアルコール (PVA: $\mathrm{n}=1.53,600 \mathrm{~nm})$ を用 い, それぞれトルエン，水を溶媒として使用している。 PS とPVAの屈折率差が小さいため, 実にH, L層を合計 170層も積層して90\%以上の反射率を得ている。また最 近，A. L. Alvarez ${ }^{12)}$ らは，H層にポリビニルカルバゾール
$(\mathrm{PVK}: \mathrm{n}=1.72 ， 550 \mathrm{~nm}) ， \mathrm{~L}$ 層にPVA $(\mathrm{n}=1.55,550 \mathrm{~nm})$ を用い, それぞれトルエン, 水を溶媒として作製した結 果を報告している，H層，L層を合計20層ほど積層し，50 \%程度の反射率が得られている。 これらスピンコート法に よる多層膜作製に共通するのは, $\mathrm{HL}$ 各層とも入/4光学膜厚 の制御が不十分であるため高反射帯域幅が非常に狭く なってしまい，それに付随して高反射を得るために積層 数をさらに多くする必要がある点，目標波長における高 反射を実現できていない点，作製環境に左右されやすい 水溶性ポリマーを使用している点である. 筆者らの成果 は第2，3の問題点を克服している.

スピンコート法による多層膜作製の際，材料に求めら れる条件は(1)高屈折率, 低屈折率ポリマーの屈折率比 $n_{\mathrm{H}} /$ $n_{\mathrm{L}}$ が大きいこと, (2)多層構造構築のため2種のポリマーに 対する溶媒は互いに非溶媒であること, (3)低吸収, 低散 乱なアモルファスポリマーであることである。これらの 条件を満たすポリマーとしてH層にPVK，L層にセルロー スアセテート $(\mathrm{CA}: \mathrm{n}=1.48, \mathrm{Na} \mathrm{D}$ 線)を選択した. 上記の 例に比べると，これら2種のポリマーの組合せからはより 大きな屈折率比が得られ，水溶性ポリマーを用いないと いう利点がある。PVKは様々なポリマーの中でも屈折率 が1.68(Na D線) と大きく，一般的な有機溶媒に可溶である が, エステル系・アルコール系溶媒には溶解しない特性 をもっている。一方，半合成高分子として知られている $\mathrm{CA}$ ，側鎖の水酸基のエステル化の程度 (酢化度)によっ て溶媒に対する溶解性が大きく変化するポリマーであ る。このCAの特性を溶解度制御に利用し，H層にPVKそ の溶媒にはCAを溶解しないクロロベンゼン，L層には酭 化度55\%のCAその溶媒にはPVKを溶解しないジアセトン アルコールの組合せを用いた。

スピンコート法による薄膜作製においては, 無機材料 を蒸着する際の水晶振動子による厚さモニターはできな い. 膜厚制御に関しては当初, 材料の正確な屈折率の值 を知る必要があると考えていたが, 以下の手順で入/4光学 膜厚制御が可能であることがわかった。（11まず，NaD線 でのポリマー屈折率と触針法によるガラス基板上の単層 膜厚測定を基に， $\lambda / 4$ 光学膜厚を与える溶液濃度を大まか に見積もる。(2)見積もりょり若干濃い溶液から単層膜を 作製し. 分光光度計を用いて単層膜の透過率を測定す るＨ層であるPVKの場合は最小透過率，L層であるCAの 場合は最大透過率を与える $\lambda / 4$ 光学膜厚の波長 $\lambda$ を求める. この波長入は目標とする設計波長より長くなるようにして おく. (3)このポリマー溶液に溶媒を加え, 徐々に溶液濃 度を下げつつ単層膜透過率を測定し, 設計波長の $\lambda / 4$ 光学 膜厚に近づける。(4)設計波長の $\lambda / 4$ 光学膜厚に近づいたら スピナー回転数を微調整する．以上により，設計波長に 対する溶液濃度およびスピナー回転数を決定する.

決定された溶液濃度, スピナー回転数を用い, 1 層塗布 毎に $80{ }^{\circ} \mathrm{C} て ゙ 20$ 分のベーキング, 溶媒乾燥を繰り返して, ポリマー多層膜を作製した。しかしながら，基板上への 塗布と塗布した膜上への塗布では条件が多少異なる。そ こで, (5)その後の積層中の反射率最高波長が設計波長か らシフトした場合，スピナー回転数を $100 \mathrm{rpm}$ 程度微調し 
て修正しながら塗布を行う21). Fig. 2は設計波長を1064 nm として $(\mathrm{HL})$ の周期数 $18 /$ 合計 39 層, 積層した例である。層 数増加に伴う透過率の減少つまり反射率の増大が確認さ れる。しかし，1064 nmに拈ける透過率は10\%，最小透過 率2\%は1028 nmで得られている。これは層毎の膜厚に $\lambda / 4$ 光学膜厚からのずれがあったことが理由である. 反射率 最高波長の積層毎のシフト量からずれを見積もったとこ ろ，1層あたり $0.04 \times \lambda / 4$ 光学膜厚，8９ nmであることが わかった。設計波長からのシフトを積層毎に補正できる か否か, 理論的に評価した結果がFig. 3である. Fig. 3は, 15 層まで $0.96 \times \lambda / 4$ 光学膜厚, 15 層以降 $1.02 \times \lambda / 4$ 光学膜厚と したもので次第に設計波長に近ついている。実験ではこ の修正をもっと初期の積層段階で行った結果, 様々な設 計波長に対してほほ設計波長通りの反射率を得ることが 可能となった.

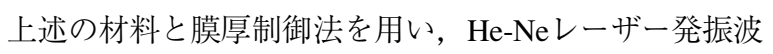

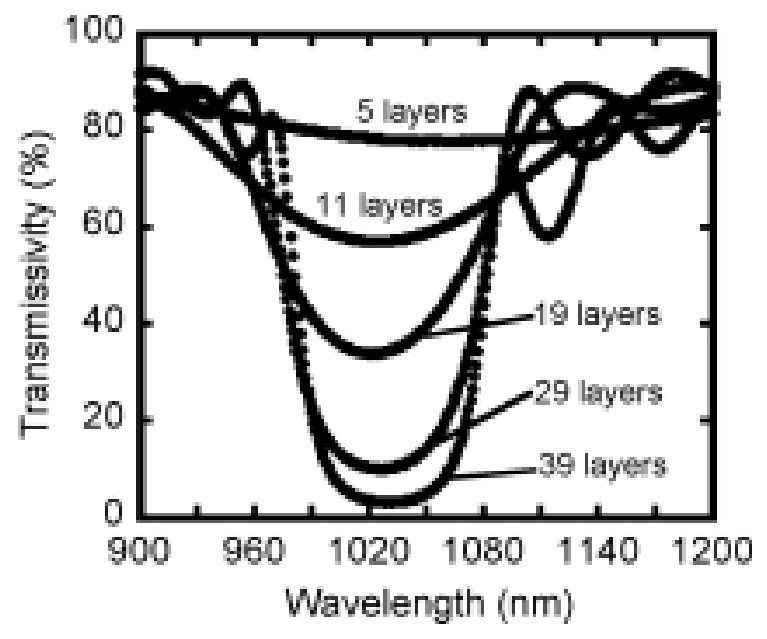

Fig. 2 Transmission spectra of multi-layered mirrors. Numbers of stacked layers are shown in the figure.

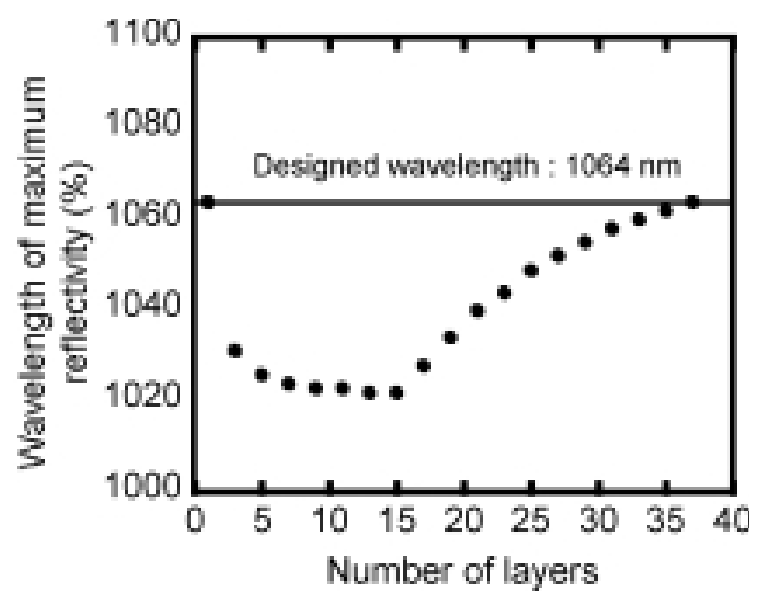

Fig. 3 Theoretically calculated plots. They are plotted assuming $4 \%$ thinner deviation from a designed quarter-wavelength in stacking 15 layers except for the 1st layer and $2 \%$ thicker correction in stacking the 16 th to the 39 th layer. The wavelength of the maximum reflectivity is shown for each of the oddnumbered layers. Here, the designed wavelength is $1064 \mathrm{~nm}$.
長633 nmを設計波長として，溶融石英基板上に作製した 高反射多層膜の透過率スペクトルをFig. 4に示す. 積層数 は49層である. Fig. 5は作製されたミラーの写真である。 左が無機誘電体多層膜ミラー, 右がポリマー多層膜ミ ラーである。透過率が1\%以下に抑えられたストップ・バ ンドが存在しているのがわかる. 面内の反射率の均一性 は無機誘電体ミラーとほぼ同程度であった. 以上の結果 は, 繰り返し積層の再現性があること, 1層の膜厚制御の 精度がnm程度であることを示しており，“ローテクによる ナノテク”であるといえる。

\section{4. ポリマー多層膜を用いた光素子}

4.1 マイクロチップ $\mathrm{Nd}^{3+}: \mathrm{YVO}_{4}$ レーザーの連続およ びQスイッチ発振

上記の方法で作製したポリマー多層膜をマイクロチッ プ $\mathrm{Nd}^{3+}$ : $\mathrm{YVO}_{4}$ レーザーの出力ミラーとして使用して連続 (CW) およびQスイッチ発振 21 )を確認した。まず， $\mathrm{Nd}^{3+}$ : YAGレーザーを照射して表面反射率分布を測定したとこ ろ， $10 \times 10 \mathrm{~mm}^{2}$ の範囲において平均反射率 $90.6 \%$, 標準偏

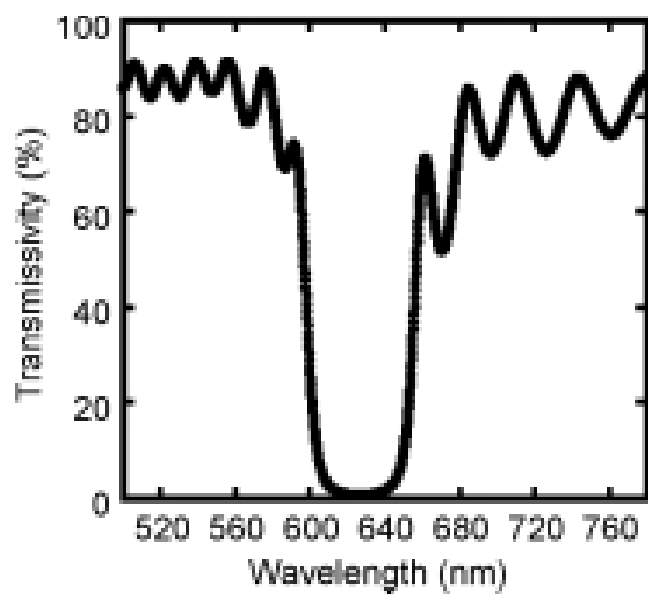

Fig. 4 Transmission spectrum of a multi-layered mirror with 49 stacked layers for a designed wavelength of 633 nm.

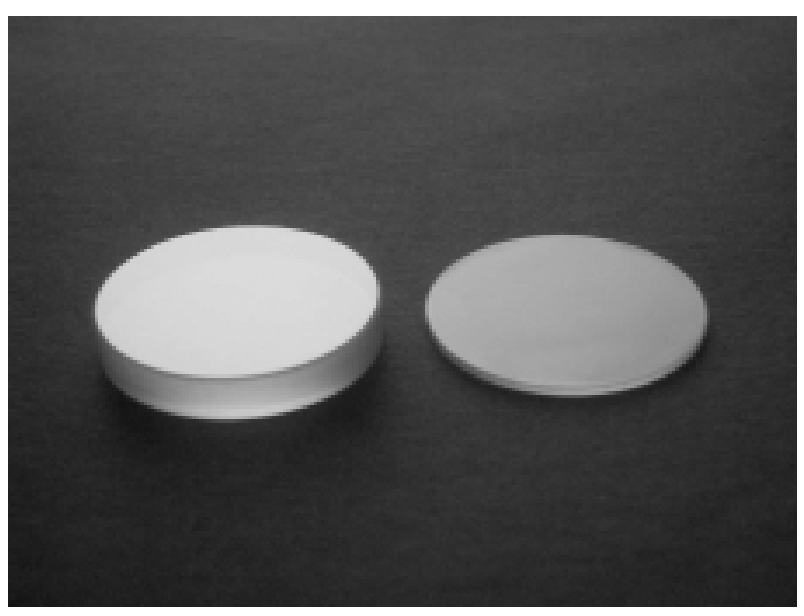

Fig. 5 Photograph of the polymeric multi-layer-coated mirror. For comparison, an inorganic mirror is shown in the left-hand side. 
差 $2.1 \%(1064 \mathrm{~nm})$ の反射率分布であった。このポリマー多 層膜平面ミラーを用いたCW発振では, 励起半導体レー

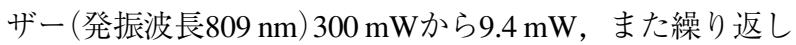
レート $1.42 \mathrm{kHz}$ のスイッチ発振では, 同じ励起パワーか ら平均パワー $0.4 \mathrm{~mW}$, ピークパワー7.6 Wが得られた. Q スイッチ動作には圧電ポリマー，ポリフッ化ビニリデン (PVDF) を使用した. Fig.6に示すように，分極方向が逆向 きになるように張り合わせたバイモルフ構造のポリマー (厚さ $120 \mu \mathrm{m})$ を用い, 1 辺を固定して数 $100 \mathrm{~V}$ の AC電圧を 印加すると $10 \mathrm{~mm}$ 長の先の自由端が左右に $\pm 10 \mathrm{~mm}$ ぼの 振幅で振動する．振動する出力ミラーを用いれば，かつ て使われたことのある回転鏡，回転プリズムと同様にQス イッチ動作が得られる。実験はこのバイモルフ・ポリ マーにカバー・ガラス基板のミラーを装着して行われ た。しかしながら実用的な素子を考えると, 透明圧電ポ リマー自身をミラー化することが望ましい。そのような ことを可能にするのが，スピンコート法で得られるフレ キシブルなポリマー多層膜である.

\section{2 光制御素子その他}

高反射ミラーを対向させて配置するファブリ・ペロー 干渉フィルターの研究・開発対象として, 光通信におけ るチャネル切換スイッチ22) などがある他, 1次の電気光学 (EO) 材料や圧電材料を中間層として用い, ストップ・バ ンドあるいはフォトニック結晶禁制バンド中の不純物レ ベルを制御して低電圧駆動の変調素子とする動きもあ る。いずれの機能素子もポリマー多層膜を用いれば，中 間層も電場配向ポリマー23)や無機圧電材料に比べて極め て大きな変位・変形が得られる圧電ポリマーとすること によって，一体化されたコンパクトな素子を構成するこ とができる。

積層するポリマー自身の機能化ができれば，低電圧駆 動・高速のファブリ・ペローEOポリマーやファブリ・ペ ロー圧電ポリマーが構築できる他，レーザー色素をドー プして波長同調可能な色素レーザー，非線形色素を取り 込んで高効率波長変換素子なども構築可能である.

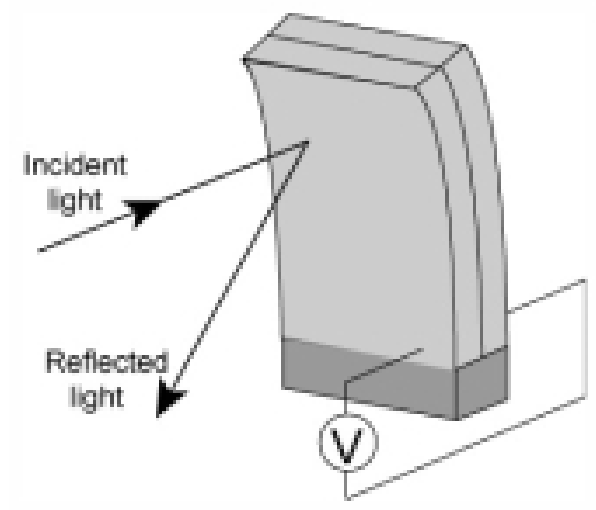

Fig. 6 Bending of a bimorph structure of polymers.

\section{5. 耐光性}

ポリマーの光素子化を考える上で, その材料や素子構 造に依存する耐光性の評価は重要である。バルク状の物 質に比べると光学薄膜のレーザー損傷しきい值 (LIDT: Laser-Induced Damage Threshold)は低い. LIDTの向上のた め, $\lambda / 4$ 光学膜厚以外での設計や保護膜塗布などが試みら れている24,25)。また，レーザー色素をドープしたポリマー のLIDT評価の例26)もある。一般的にLIDTは機構が多種多 様であるため, 定量的評価は困難で用途に応じた損傷試 験が必要となる。

筆者らはその定量化を考え3次の非線形光学効果の評価

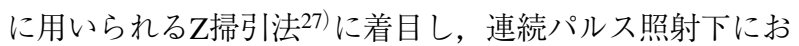
いて，1064 nmに対して異なる反射率を有するポリマー多 層膜のLIDT評価を行った。光源には繰り返しレート 10 $\mathrm{Hz}$ ，パルス幅9nsの $\mathrm{Nd}^{3+}: \mathrm{YAG}$ ーザーを用いた。 サンプ ルを光軸方向に掃引することで照射ビーム強度を変化さ せ，透過光プロファイルを測定，そのプロファイル変化 から損傷しきい值を見積もった結果をTable 1 に示す。積層 数増加に伴い損傷しきい值が下がる傾向にあり, 積層に 伴う内部定在波電界の増加を示唆する結果を得た。一般 的な比較はできないが, 無機誘電体多層膜と比べると損 傷しきい值は1桁小さい值となった。また，損傷機構は PVKの場合フォト・ブリーチングであったが, CAの場合 は未解明である。

\section{6. まとめと課題}

種々の多層膜作製法の中でも真空環境を必要としない ポリマーのスピンコート法は，簡便で低コストであるだ けでなく，無機材料のみによる多層膜では考えられない 様々な素子への応用も期待できる。課題は，(1)ポリマー の屈折率がおよそ1.3〜 1.7の範囲にあるため, 高い屈折率 比が得られないこと, (2) 溶媒との相溶性を考慮しなけれ ばならないため選択するポリマーに制約があること，(3) 短波長域反射ミラー作製においては薄い $\lambda / 4$ 光学膜厚を必 要とするが，その際，本稿では述べなかった既製下層へ の溶媒の浸透が起きることなどである。（1）の課題に対し ては, ナノ微粒子分散, 色素分散などが考えられる。 (2)，（3）の課題に対しては，UV架橋樹脂等を用いる耐薬 品性の向上などがあり得る。いずれも材料開発に携わる 化学系の研究者, 技術者の協力無くしては解決できない

Table 1 Laser-induced-damage threshold of polymeric multilayered mirrors.

\begin{tabular}{ccc}
\hline $\begin{array}{c}\text { Number of } \\
\text { stacked layers }\end{array}$ & $\begin{array}{c}\text { Reflectivity }(\%) \\
\text { @ } 1064 \mathrm{~nm}\end{array}$ & $\begin{array}{c}\text { LIDT } \\
\left(\mathrm{MW} / \mathrm{cm}^{2}\right)\end{array}$ \\
\hline 7 & 38 & $138 \pm 85$ \\
11 & 53 & $71 \pm 37$ \\
17 & 71 & $72 \pm 22$ \\
21 & 82 & $41 \pm 14$ \\
27 & 89 & $38 \pm 6$ \\
\hline
\end{tabular}


14) K. M. Lenahan, Y. Liu, and R. O. Claus: Proc. SPIE 3675 (1999) 74.

\section{参考文献}

1) U. Schulz, U. B. Schallenberg, and N. Kaiser: Appl. Opt. 42 (2003) 1346 .

2) W. T. Pawlewicz, P. M. Martin, R. W. Knoll, and I. B. Mann: Proc. SPIE 678 (1986) 134

3) S. A. Jenekhe: Ind. Eng. Chem. Fundam. 23 (1984) 425

4) C. J. Lawrence: Phys. Fluids. 31 (1988) 2786.

5) D. Meyerhofer: J. Appl. Phys. 49 (1978) 3993.

6) R. Chow, G. E. Loomis, and R. L. Ward: J. Vac. Sci. Technol. A 14 (1996) 63.

7) A. Convertino, A. Valentini, T. Ligonzo, and R. Cingolani: Appl. Phys. Lett. 71 (1997) 732

8) A. Convertino, A. Valentini, and R. Cingolani: Appl. Phys. Lett. 75 (1999) 322.

9) N. Kambe, Y. D. Blum, B. Chaloner-Gill, C. Honeker, and D. B. MacQueen: Proc. SPIE 4905 (2002) 1.

10) P. K. H. Ho, N. Tessler, and R. H. Friend: Synth. Metals 102 (1999) 1020.

11) M. Kimura, K. Okahara, and T. Miyamoto: J. Appl. Phys. 50 (1979) 1222.

12) A. L. Alvarez, J. Tito, M. B. Vaello, P. Velasquez, R. Mallavia, M M. Sanchez-Lopez, and S. Fernandez de Avila: Thin Solid Films 433 (2003) 277

13) H. Kosonen, S. Valkama, J. Ruokolainen, M. Torkkeli, R. Serimaa, G. ten Brinke, and O. Ikkala: Eur. Phys. J. E 10 (2003) 69.
15) D. P. Partlow and T. W. O'Keeffe: Appl. Opt. 29 (1990) 1526.

16) H. Jiang, W. E. Johnson, J. T. Grant, K. Eyink, E. M. Johnson, D. W. Tomlin, and T. J. Bunning: Chem. Mater. 15 (2003) 340.

17) K. Tai, L. Yang, Y. H. Wang, J. D. Wynn, and A. Y. Cho: Appl Phys. Lett. 56 (1990) 2496.

18) P. K. H. Ho, D. S. Thomas, R. H. Friend, and N. Tessler: Science 285 (1999) 233.

19) T. Fujihara, T. Komikado, A. Inoue, and S. Umegaki: The $87^{\text {th }}$ OSA annual meeting Frontiers in Optics / Laser Science XIX, Tucson, October (2003) 77.

20) T. Komikado, T. Fujihara, A. Inoue, K. Kino, T. Iwamura, and S Umegaki: $7^{\text {th }}$ International Conference on Organic Nonlinear Optics / International Conference on Organic Photonics and Electronics, Sorak, November (2003) 202.

21）小見門利行，井上梓，増田 康一，藤原隆，梅垣 真祐：O plus E 26 (2004) 171.

22) M. Lequime, R. Parmentier, F. Lemarchand, and C. Amra: Appl. Opt. 41 (2002) 3277.

23) K. Harada, K. Munakata, M. Itoh, N. Yoshikawa, H. Yonezu, S Umegaki, and T. Yatagai: Jpn. J. Appl. Phys. 37 (1998) 4393.

24) J. H. Apfel: Appl. Opt. 16 (1977) 1880.

25) S. Motokoshi, H. Yoshida, K. Yoshida, T. Yamanaka, and S. Nakai: Jpn. J. Appl. Phys. 33 (1994) L1530.

26) W. J. Wadsworth, S. M. Giffin, I. T. McKinnie, J. C. Sharpe, A. D. Woolhouse, T. G. Haskell, and J. Smith: Appl. Opt. 38 (1999) 2504

27) M. S. Bahae, A. A. Said, T. H. Wei, D. J. Hagan, and E. W. V Stryland: IEEE J. Quantum Electron. 26 (1990) 760. 